\title{
A pivotal peptide (Ile-Leu-Lys-Pro) with high ACE- inhibitory activity from duck egg white: identification and molecular docking
}

\author{
Haitao $\mathrm{LI}^{1}$, Xiaoyan $\mathrm{CHEN}^{1}$, Yan $\mathrm{GUO}^{1}$, Tao $\mathrm{HOU}^{2 \star}$ (D), Jun $\mathrm{HU}^{2}$
}

\begin{abstract}
Salted duck egg white was desalted and hydrolyzed to produce angiotensin I-converting enzyme (ACE) inhibitory peptides. Single factor test and response surface design were performed to determine the best hydrolysis conditions: enzyme dosage $11875.99 \mathrm{U} / \mathrm{g}$, substrate concentration $33.04 \mathrm{~g} / \mathrm{L}$ and hydrolysis time $4 \mathrm{~h}$. The fraction $\mathrm{V}\left(\mathrm{M}_{\mathrm{w}}<1 \mathrm{kDa}\right)$, which exhibited the strongest ACE inhibitory activity, was characterized by HPLC-ESI-MS/MS. Eighty-three peptides were identified, and among them Ile-Leu-Lys-Pro, Ile-Asn-Ser-Trp, Ile-Arg and His-Pro-Ala were synthesized for further research. Ile-Leu-Lys-Pro exhibited the highest ACE inhibitory activity $\left(\mathrm{IC}_{50}: 0.355 \mathrm{mM}\right)$. The molecular docking studies revealed that nine amino acids contributed to stabilize the docking complex. The ACE inhibition of Ile-Leu-Lys-Pro and Ile-Asn-Ser-Trp were mainly attributed to Ile in $\mathrm{N}$-terminal. The residues Glu362 and Ala332 were the important binding sites in molecular docking. This research expands the understanding of ACE inhibitory peptides from duck egg white as well as highlights an opportunity for recycling an otherwise discarded byproduct.
\end{abstract}

Keywords: desalted duck egg white peptides (DPs); enzymatic hydrolysis; angiotensin I-converting enzyme (ACE) inhibitory peptide; electrospray ionization mass spectrometry (ESI-MS); molecular docking.

Practical Application: Results in this research can be used for the intensive processing of duck egg white, especially for the recycling of salted duck egg white. The obtained polypeptide with antihypertensive activity can be used for the development of functional food and improvement of food industry.

\section{Introduction}

Angiotensin converting enzyme (ACE) has a significant impact on the regulation of blood pressure and it promotes the transformation of angiotensin I to angiotensin II by inactivating the potent vasodilator bradykinin in the circulatory or endocrine of human renin-angiotensin system (Jimsheena \& Gowda, 2010). A high level of ACE inhibitory activity was effective in antihypertensive activities (Mirdhayati et al., 2016). Thus, ACE is identified as a potential target for synthetic pharmaceuticals, which inhibited ACE activity to reduce blood pressure. Compared with pharmacological agents, peptides derived from natural food with high ACE inhibitory activity were preferred for their safety (Ngo et al., 2016). In consideration of this, ACE inhibitory peptides are proposed as ideal functional food supplements for human health (Feng et al., 2016).

It has been reported that bovine collagen was a potential precursor of ACE inhibitory peptides based on in silico and in vitro protein digestions and two promising in silico peptides (Tyr-Trp and Leu-Arg-Tyr) were confirmed as novel ACE inhibitors (Fu et al., 2016). Porcine skin gelatin was also hydrolyzed with a targeted enzymatic approach (Aspergillus niger prolyl endoproteinase) to produce hydrolysate with potent ACE inhibitory activity after 4-h hydrolysis and the sequence was identified as Met-Gly-Pro (O’Keeffe et al., 2017). Besides animal source, plant protein like soybean and grain is also an abundant source of ACE inhibitory peptides. Leu-Ser-Trp was previously identified from thermolysin-digested soy protein hydrolysate as a potent ACE-inhibitory peptide (Lin et al., 2017). Sweet sorghum grain protein hydrolysate was fractionated to four fractions ( $>10,5-10,1-5$ and $<1 \mathrm{kDa}$ ) by ultrafiltration, with the $<1 \mathrm{kDa}$ fraction exhibited the strongest ACE inhibitory activity (Wu et al., 2016).

Salted duck egg is one of the most popular and traditional preserved egg products in both Southeast Asia and China, and it contains all essential amino acids for human beings (Kaewmanee et al., 2011). Due to the content of 7-10\% sodium chloride, large amounts of salted duck egg white are discarded every year (Zhao et al., 2014). After hydrolysis by enzyme, hen egg white is reported to possess many functions such as antiinflammatory, antimicrobial, ACE-inhibitory and antidiabetic activities (Abeyrathne et al., 2018; Grootaert et al., 2017; Yu et al., 2012). Meanwhile, the ACE inhibitory activity was explored by hydrolyzing different proteins, such as grain and milk protein (Connolly et al., 2015; Vukic et al., 2017). However, the utilization of desalted duck egg white to produce the ACE inhibitory peptides have not been reported. 
Therefore, in the present study, we attempted to optimize the hydrolysis conditions of desalted duck egg white for the preparation of ACE inhibitory peptides. The main ACE inhibitory peptides were isolated and identified to investigate their ACEinhibitory activity. Additionally, the peptide with the highest ACE inhibitory activity was synthesized to characterize its stability during the simulation in molecular docking process.

\section{Materials and methods}

\subsection{Materials and chemicals}

Salted duck egg white with a sodium chloride content of 7\% and a protein content of $10 \%$ was donated by Hubei Shendan Healthy Food Co., Ltd. (Wuhan, China). Neutrase $0.8 \mathrm{~L}$, alcalase $2.4 \mathrm{~L}$, papain, protamex, flavourzyme, trypsin and pepsin were purchased from Novozymes (Copenhagen, Denmark). ACE were isolated from fresh hog lung. Angiotensin I-converting enzyme (ACE) Elisa kits were purchased from the PLA navy hospital (Beijing, China). Polymeric-Cellulose spiral-wound membranes, including molecular weight cut-off (MWCO) at $1 \mathrm{kDa}, 3 \mathrm{kDa}$, $5 \mathrm{kDa}$ and $6 \mathrm{kDa}$, were purchased from Millipore Inc. (Billerica, Massachusetts, USA). HPLC-grade acetonitrile was purchased from Fisher Chemical (Fair Lawn, NJ, USA), and HPLC-grade water was prepared using a Milli-Q system (Millipore Iberica, Madrid, Spain). Trifluoroacetic acid (TFA) of HPLC grade was purchased from Sigma Chemical Co. (Saint Louis, MO, USA). All other chemicals and solvents were of analytical grade.

\subsection{Preparation of desalted duck egg white and Angiotensin I-Converting Enzyme (ACE)}

Salted duck egg white was desalted by the electro-dialysis equipment (QQX, Zhejiang Qianqiu Environmental Water Treatment Co., Ltd, Hangzhou, China) as reported in our previous work (Zhao et al., 2014). The angiotensin I-converting enzyme (ACE) was prepared as described previously (Cushman \& Cheung, 1971) with minor modification.

\subsection{Enzymatic hydrolysis and assay of Degree of Hydrolysis (DH)}

The desalted duck egg white was hydrolyzed by seven enzymes: Neutrase $0.8 \mathrm{~L}\left(50^{\circ} \mathrm{C}, \mathrm{pH} 7.0\right)$, alcalase $2.4 \mathrm{~L}\left(55^{\circ} \mathrm{C}, \mathrm{pH} 8.0\right)$, papain $\left(55^{\circ} \mathrm{C}, \mathrm{pH} 6.0\right)$, protamex $\left(50^{\circ} \mathrm{C}, \mathrm{pH} 6.5\right)$, flavourzyme $\left(50{ }^{\circ} \mathrm{C}, \mathrm{pH} 6.5\right)$, trypsin $\left(40{ }^{\circ} \mathrm{C}, \mathrm{pH} 7.8\right)$ and pepsin $\left(37^{\circ} \mathrm{C}\right.$, $\mathrm{pH}$ 2.0). After water bath at $70{ }^{\circ} \mathrm{C}$ for $40 \mathrm{~min}$, the hydrolysis process was conducted. The supernatant was lyophilized after centrifugation and used for the determination of ACE inhibitory activity and the degree of hydrolysis (DH).

As for the single factor experiments, the independent variables contain Substrate concentrations (pure protein concentrations) of 20,30,40,50 and $60 \mathrm{~g} / \mathrm{L}$, Enzyme dosages of 5000, 10000,15000, 20000 and $25000 \mathrm{U} / \mathrm{g}$, and Hydrolysis time of $20000 \mathrm{U} / \mathrm{g}$ for $2,3,4,5$ and $6 \mathrm{~h}$. The other hydrolysis conditions were: hydrolysis temperature $50{ }^{\circ} \mathrm{C}, \mathrm{pH}$ 6.5. The degree of hydrolysis $(\mathrm{DH})$ and ACE inhibitory activity were investigated after enzymatic reaction. The $\mathrm{DH}$ was determined by the $\mathrm{pH}$-stat method and calculated using the following Equation 1:
$D H(\%)=B \times N b /(\alpha \times M p \times h t o t) \times 100$

Where htot is the total number of peptide bonds in the protein substrate $(11.1 \mathrm{mmol} / \mathrm{g}$ protein).

\subsection{Response Surface Design (RDS)}

A Box-Behnken experimental design (BBD) was used to optimize the hydrolysis conditions. The following independent variables were selected: hydrolysis time $\left(\mathrm{X}_{1}, 2,3,4 \mathrm{~h}\right)$, enzyme dosage $\left(\mathrm{X}_{2}, 10000,15000,20000 \mathrm{U} / \mathrm{g}\right)$ and substrate concentration $\left(\mathrm{X}_{3}, 20,30,40 \mathrm{~g} / \mathrm{L}\right)$. A three-level three-factor BBD design was employed.

\subsection{Assay of ACE inhibitory activity}

ACE inhibitory activity was analyzed by spectrophotometry using hippuryl-histidyl-leucine (HHL) as substrate, according to the method of Cushman \& Cheung (Cushman \& Cheung, 1971) with minor modifications. The details were the same as previous reports (Huang et al., 2011). The $\mathrm{IC}_{50}$ value was defined as the concentration of ACE inhibitor namely protein hydrolysate needed to reduce $50 \%$ of ACE activity and determined by regression analysis of ACE inhibitory activity (\%) versus protein concentration. The $\mathrm{IC}_{50}$ value was identified as $\mathrm{mg}$ protein $/ \mathrm{mL}$. The ACE inhibitory activity (\%) was expressed as follow (Equation 2):

$A C E$ inhibitory activity $(\%)=(A-S) /(A-C) \times 100$

Where $\mathrm{A}$ is the absorbance at $228 \mathrm{~nm}$ without protein hydrolysate; $\mathrm{S}$ is the absorbance with protein hydrolysate; and $\mathrm{C}$ is the absorbance without protein hydrolysate and ACE.

\subsection{Fractionation of ACE inhibitory peptides}

The desalted duck egg white hydrolysate was filtered sequentially through $1 \mathrm{kDa}, 3 \mathrm{kDa}, 5 \mathrm{kDa}$ and $6 \mathrm{kDa} \mathrm{Mw}$ cutoff membranes (Millipore Co., Billerica, Massachusetts, USA) and separated into five fractions: fraction $\mathrm{I}(\mathrm{Mw}>6 \mathrm{kDa})$, fraction II (Mw5 -6 kDa), fraction III (Mw 3-5 kDa), fraction IV (Mw 1-3 $\mathrm{kDa})$, fraction $\mathrm{V}(\mathrm{Mw}<1 \mathrm{kDa})$. Each fraction was assayed for ACE inhibitory activity. The highest ACE inhibitory fraction was pooled, lyophilized and stored at $-20^{\circ} \mathrm{C}$ until use.

\subsection{HPLC analysis instrumentation}

The HPLC analysis was performed on a Waters e2695 HPLCDAD system (Waters, Milford, MA, USA), equipped with a diode array detector, a vacuum degasser, an auto-sampler, a binary pump, and a column compartment. The highest ACE inhibitory fraction $(\mathrm{Mw}<1 \mathrm{kDa})$ at a concentration of $10 \mathrm{mg} /$ $\mathrm{mL}$ were analyzed on a ZORBAX SB-C18 column $(250 \mathrm{~mm} \times$ $4.6 \mathrm{~mm}, 5 \mu \mathrm{M}$, Agilent Co., Santa Clara, CA, USA) at a flow rate of $1 \mathrm{~mL} / \mathrm{min}$, with the temperature of the column maintained at $25^{\circ} \mathrm{C}$. A binary gradient elution system, comprising water (with $0.1 \%$ TFA, A) and acetonitrile (with 0.1\% TFA, B), was applied as follows: $0.0-15.0 \mathrm{~min}, 5-12 \% \mathrm{~B} ; 15.0-45.0 \mathrm{~min}, 12-35 \% \mathrm{~B}$. The volume of injection was $20 \mu \mathrm{L}$, and the DAD detector was set at $220 \mathrm{nM}$ for analysis. 


\subsection{Peptide identification by HPLC-ESI-MS/MS}

For HPLC-ESI-MS/MS analysis, the HPLC system described above was replaced by an Agilent1100 series HPLC-ESI-MS system (Agilent Technologies) but with the same column and gradient elution as in the HPLC analysis. Mass spectrometry conditions were set as follows: $\mathrm{ESI}^{+}$ion source; drying gas temperature, $365^{\circ} \mathrm{C}$; nebulizer, $40.00 \mathrm{psi}$; dry gas flow rate, $10.0 \mathrm{~L} /$ min; capillary voltage, $3500 \mathrm{~V}$; scan spectra from m/z 50 to 1000 . The sequences were identified using LCMSD-Trap Data Analysis software and confirmed by searching the online MS database on the UCSF Mass Spectrometry Facility (http://prospector.ucsf. edu/prospector/cgi-bin/msform.cgi?form=mspattern; NCBInr. 2015. 3. 10, SwissProt. 2015. 3. 5, UniProtKB.2015.3. 5).

\subsection{Molecular docking on ACE binding site}

The structure of four peptides were constructed by using MOE software. The structure was energy minimized by using steepest descent and conjugate gradient techniques (Force field: MMFF94x). The crystal structure of human ACE-lisinopril complex (PDB: 5amb) was derived from the Protein Data Bank (PDB). Before the docking, water molecules and the inhibitor lisinopril were removed in the ACE model. The polar hydrogens were then added to the ACE model. The flexible docking of peptide at the ACE-binding site was performed using the docking tool of MOE software. The docking runs were carried out on parameters (Placement: Triangle Matcher; Rescoring 1: Alpha HB; Refinement: Force field; Rescoring 2: ASE; Retain: 30) with a radius of $10 \AA$. Evaluation of the molecular docking was performed according to the scores of several scoring functions, including E_conf, E_place, E_score1, E_refine and E_score2. According to the scores and binding-energy, the best pose for each peptide was obtained.

\subsection{Statistical analysis}

Experimental data were presented as mean values \pm SD. The mean values were compared by Duncan's multiple range test at $\mathrm{P}<0.05$ using SPSS software version 17.0.

\section{Result and discussion}

\subsection{Hydrolysis of desalted duck egg white}

As shown in Figure 1D, there was no significant difference of ACE inhibitory activity in neutrase, alcalase, promamex
A

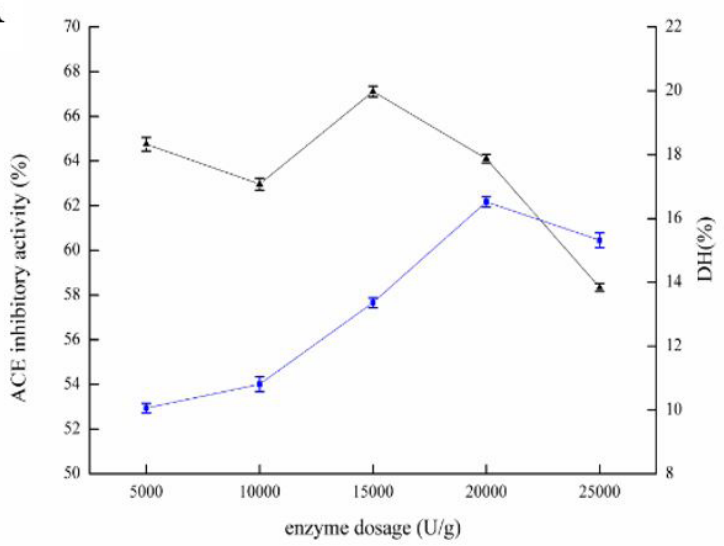

$\mathrm{C}$

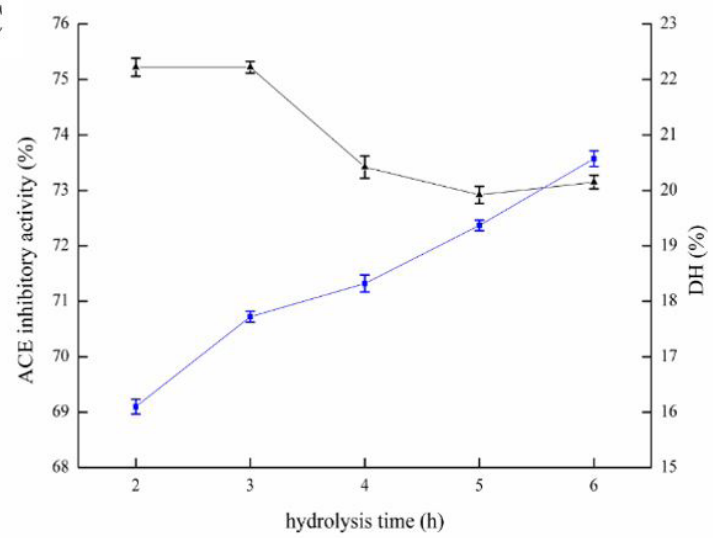

B

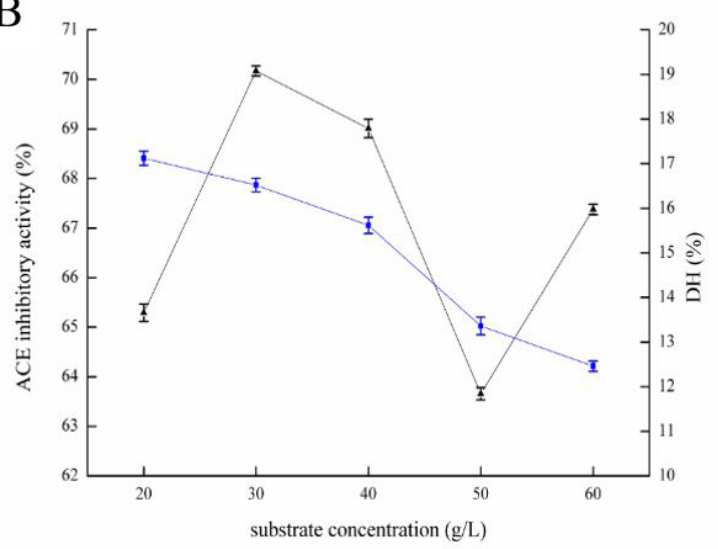

D

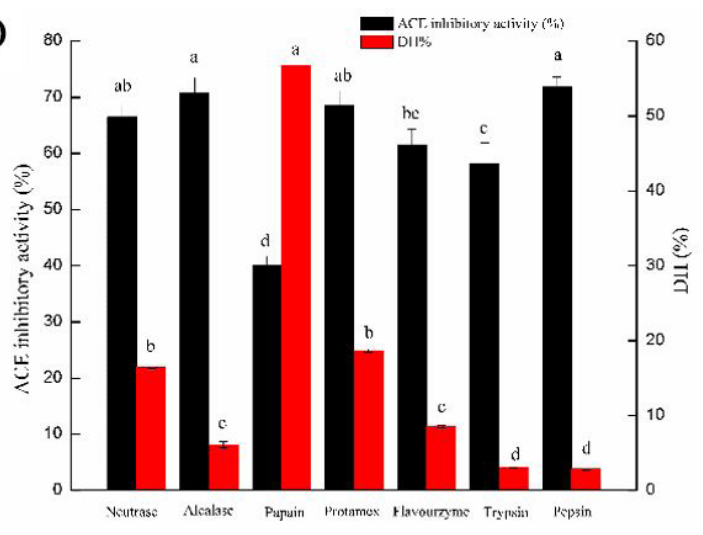

Figure 1. ACE inhibitory activity ( $\triangle \mathrm{ACE}$ and $-\mathrm{DH}$ ) of different enzyme dosage, substrate concentration and hydrolysis time. (A) Effect of the enzyme dosages on ACE inhibitory activity and DH; (B) Effect of substrate concentrations on ACE inhibitory activity and DH; (C) Effect of enzymatic hydrolysis on ACE inhibitory activity and DH; (D) ACE inhibitory activity (\%) and DH (\%) of desalted duck egg white hydrolysates by using seven kinds of proteases. Results are expressed as mean values at three replicates. 
and pepsin treatment groups, which reached $66.45 \%, 70.74 \%$, $68.45 \%$ and $71.95 \%$, respectively. The degree of hydrolysis by using promamex was slightly higher than that of neutrase and significantly higher than that of alcalase and pepsin. Therefore, promamex was chosen as the best protease. It was reported that proteases in enzymatic hydrolysis resourced from plant, animals and microorganism might have high ACE inhibitory activity relatively (Forghani et al., 2016; Pandey et al., 2018). Some previous studies found that the production of egg white enzymatic hydrolysates with alcalase and pepsin had high ACE inhibitory activity (Miguel et al., 2006; Miguel et al., 2004; Yu et al., 2011b; Liu et al., 2010). It was also demonstrated that hen egg white hydrolysate with antioxidant and antithrombin activity were prepared by using alcalase (Yu et al., 2011a). In the present study, the protamex present the characteristics of both endopeptidase and exopeptidase, constructing more enzyme cutting sites (Zhang et al., 2018).

As shown in Figure 1A, there was a constantly increase of DH from $5000 \mathrm{U} / \mathrm{g}$ to $20000 \mathrm{U} / \mathrm{g}$, followed a slightly decrease from $20000 \mathrm{U} / \mathrm{g}$ to $25000 \mathrm{U} / \mathrm{g}$. The ACE inhibitory activity reached the highest point of $67.11 \%$ when the enzyme dosage was $15000 \mathrm{U} / \mathrm{g}$, which then decreased to $58.33 \%$ till $25000 \mathrm{U} / \mathrm{g}$. It may be due to the fact that enzyme substrate ratio came much higher with the increase of enzyme dosage after $15000 \mathrm{U} / \mathrm{g}$. The high ACE inhibitory activity peptides further hydrolyzed may result in the cleavage at sites which do not facilitate ACE inhibition activity. Similar opinion was obtained by Cinq-Mars \& Li-Chan (2007), who reported a maximum of $\mathrm{ACE}$ inhibition at $3.0 \% \mathrm{E} / \mathrm{S}$ for hydrolysates of hake fillets obtained with Protamex (Cinq-Mars \& Li-Chan, 2007). In order to obtain higher ACE inhibitory activity peptides, $15000 \mathrm{U} / \mathrm{g}$ was chosen as the enzyme dosage.

Additionally, the $\mathrm{DH}$ value decreased from $20 \mathrm{~g} / \mathrm{L}$ to $60 \mathrm{~g} / \mathrm{L}$, with a sharp decrease from $40 \mathrm{~g} / \mathrm{L}$ to $50 \mathrm{~g} / \mathrm{L}$ (Figure 1B). The highest $\mathrm{DH}$ of $17.12 \%$ appeared in substrate concentration $20 \mathrm{~g} / \mathrm{L}$, which was a little higher than DH of $16.52 \%$ on the substrate concentration $30 \mathrm{~g} / \mathrm{L}$. It was observed that the ACE inhibitory activity significantly increased with the increasing substrate concentration to $30 \mathrm{~g} / \mathrm{L}$, and decreased with successional increasing substrate concentration to $50 \mathrm{~g} / \mathrm{L}$. This fact was attributed to low enzyme substrate ratio when substrate concentrate exceeded $30 \mathrm{~g} / \mathrm{L}$. The lack of enzyme led to low $\mathrm{DH}$, and the most protein was hydrolyzed to long peptides with low ACE inhibitory activity. It was reported that the effective ACE inhibitory peptides always contained 2-15 amino acid residues (Li et al., 2015). Therefore, the desalted duck egg white was not hydrolyzed adequately when substrate concentrate was higher than $30 \mathrm{~g} / \mathrm{L}$.

Figure 1C showed almost converse trends of ACE inhibitory activity and $\mathrm{DH}$ with the change of hydrolysis time. It was found that the DH increased from 2 to 6 hours, while the ACE inhibitory activity decreased from 3 to 5 hours. The ACE inhibitory activity kept the highest of $75.22 \%$ from 2 to 3 hours. This result illustrated that the appropriate hydrolysis time was key indicator in enzyme hydrolysis reaction. Though the $\mathrm{DH}$ was constantly higher, the ACE inhibitory activity declined because of the over hydrolysis. It was reported that $\mathrm{DH}$ increased in the hydrolysis of small-spotted catshark hydrolysate with ACE inhibitory activity by using subtilisin and trypsin in the first $30 \mathrm{~min}$. However, the ACE inhibition activity was not observed to increase when the DH was over 14\% (Garcia-Moreno et al., 2015). Overall, the single indicator reaction condition was optimized to the hydrolysis time $3 \mathrm{~h}$, the substrate concentration $30 \mathrm{~g} / \mathrm{L}$ and the enzyme dosage $15000 \mathrm{U} / \mathrm{g}$.

\subsection{Optimization of enzymatic hydrolysis by response surface design}

The response surface was drawn from the Box-Behnken experimental results. The influence of different hydrolysis factors on ACE inhibitory activity of desalted duck egg white protein hydrolysate was analyzed. Table 1 showed that the enzyme dosage was the most significant factor followed by the hydrolysis time. However, the substrate concentration had no significant influence on the ACE inhibitory activity. The quadratic terms of $\mathrm{X}_{2} \mathrm{X}_{2}, \mathrm{X}_{3} \mathrm{X}_{3}$ and the interaction term of $\mathrm{X}_{1} \mathrm{X}_{2}$ were significant in ACE inhibitory activity. According to the multiple regression analysis, the following second-order polynomial regression equation (Equation 3) could explain the experimental data:

Table1. Variance analysis of the experimental results of BBD.

\begin{tabular}{|c|c|c|c|c|c|c|}
\hline Source & Sum of squares & d.f. & Mean square & F-value & P-value & Note \\
\hline Model & 141.94 & 9 & 15.77 & 10.62 & 0.0090 & significant \\
\hline $\mathrm{X}_{1}$ & 17.23 & 1 & 17.23 & 11.60 & 0.0191 & \\
\hline $\mathrm{X}_{2}$ & 0.74 & 1 & 0.74 & 0.50 & 0.5111 & \\
\hline $\mathrm{X}_{3}$ & 27.4 & 1 & 27.4 & 18.45 & 0.0077 & \\
\hline $\mathrm{X}_{1} \mathrm{X}_{2}$ & 19.55 & 1 & 19.55 & 13.17 & 0.0151 & \\
\hline $\mathrm{X}_{1} \mathrm{X}_{3}$ & 3.67 & 1 & 3.67 & 2.47 & 0.1768 & \\
\hline $\mathrm{X}_{2} \mathrm{X}_{3}$ & 0.05 & 1 & 0.05 & 0.034 & 0.8615 & \\
\hline $\mathrm{X}_{1}^{2}$ & 0.69 & 1 & 0.69 & 0.47 & 0.5248 & \\
\hline $\mathrm{X}_{2}^{2}$ & 59.77 & 1 & 59.77 & 40.25 & 0.0014 & \\
\hline $\mathrm{X}_{3}^{2}$ & 18.16 & 1 & 18.16 & 12.23 & 0.0173 & \\
\hline Residual & 7.42 & 5 & 1.48 & & & \\
\hline Lack of fit & 7.02 & 3 & 2.34 & 11.61 & 0.0803 & Non-significan \\
\hline Pure error & 0.4 & 2 & 0.2 & & & \\
\hline Cor.total & 149.36 & 14 & & & & \\
\hline
\end{tabular}


$Y=34.02590+0.30807 \cdot X_{1}+1.74779 \cdot X_{2}+2.79826 E-0.03 \cdot X_{3}+0.22108 \cdot X_{1} X_{2}-$ $1.91525 E-0.04 \cdot X_{1} X_{3}+2.23818 E-0.06 \cdot X_{2} X_{3}-0.4330 \cdot X_{1}{ }^{2}-0.040235 \cdot X_{2}{ }^{2}-$ $8.86989 E \cdot X_{3}^{2}$

The determination coefficient indicated that the model was adequate for prediction within the range of the experimental variables. The low $\mathrm{P}$-value $(P<0.001)$ suggested that this model was statistically significant. Meanwhile, the response surface and contour plots (Figure 2) showed the interactive effects of three hydrolysis parameters on ACE inhibitory activity of hydrolysate. These plots displayed the responses to two independent variables and the point of maximum activity. It was observed that ACE inhibitory activity increased until enzyme dosage, substrate concentration and hydrolysis time reach an optimum point and then started to decrease. The optimal conditions were predicted by numerical optimization of the Design Expert software. The optimum conditions of the three different factors were as follows: enzyme dosage $11875.99 \mathrm{U} / \mathrm{g}$, substrate concentration $33.04 \mathrm{~g} / \mathrm{L}$ and hydrolysis time $4 \mathrm{~h}$. Under these conditions, the predicted ACE inhibitory activity was $83.87 \%$. In order to confirm the accuracy of the model, the experiment was conducted under
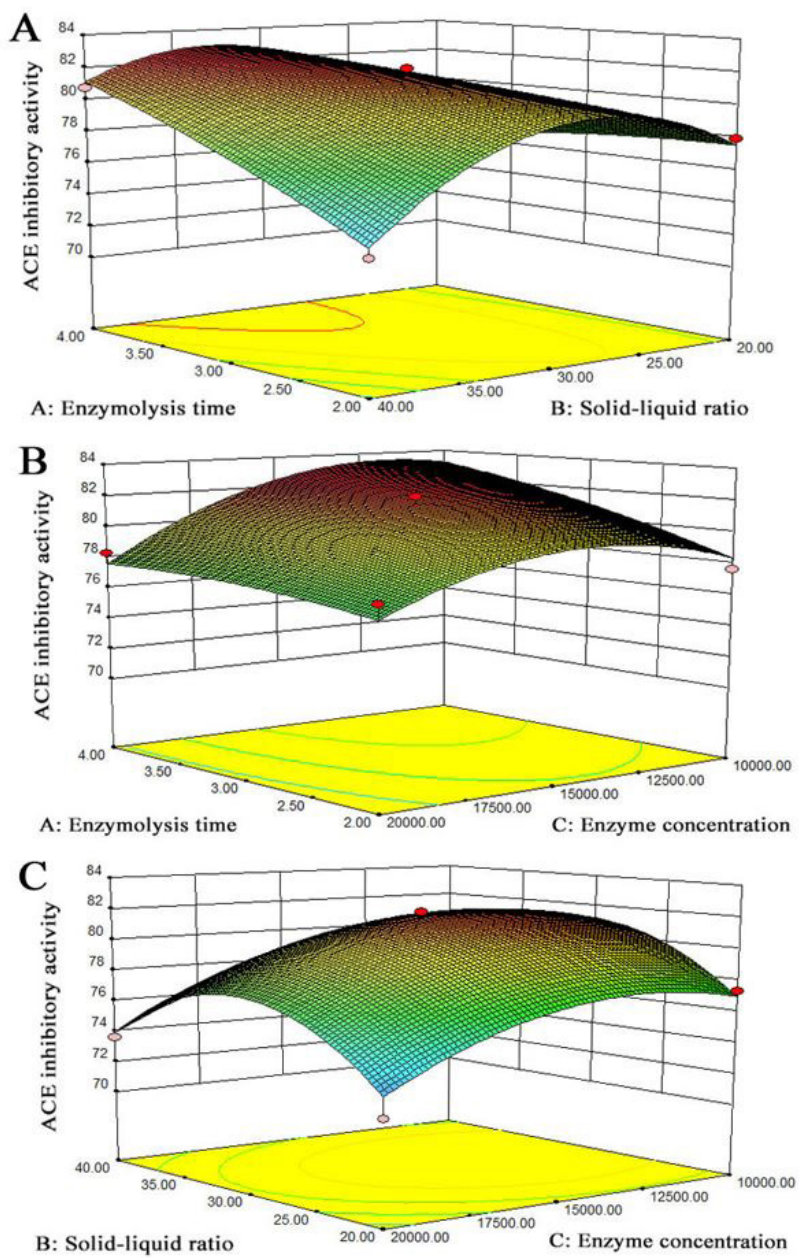

Figure 2. Response surface and contour plots showing the interactive effects of three hydrolysis parameters on ACE inhibitory activity of duck egg white peptides. optimal conditions and the ACE inhibitory activity was $84.94 \%$, which was in agreement with the predicted value. These results indicated that the employed model was adequate to predict the hydrolysis condition and confirmed that the deduced conditions are optimal for ACE inhibitory peptides from desalted duck egg white.

\subsection{Ultrafiltration and identification of ACE inhibitory peptides}

Ultrafiltration was performed to separate desalted duck egg white peptides from the optimal hydrolysis conditions into five fractions: fraction $\mathrm{I}\left(\mathrm{M}_{\mathrm{w}}>6 \mathrm{kDa}\right)$, fraction II $\left(6 \mathrm{kDa}>\mathrm{M}_{\mathrm{W}}>5 \mathrm{kDa}\right)$, fraction III ( $\left.5 \mathrm{kDa}>\mathrm{M}_{\mathrm{W}}>3 \mathrm{kDa}\right)$, fraction IV $(3 \mathrm{kDa}>\mathrm{MW}$ $>1 \mathrm{kDa})$ and fraction $\mathrm{V}(\mathrm{MW}<1 \mathrm{kDa})$. The ACE inhibitory activity of all fractions were exhibited in Figure 3. It was found that the fractions III to $\mathrm{V}$ were significantly higher than fractions I and II in ACE inhibitory activity. The fraction $\mathrm{V}$ revealed the highest ACE inhibitory activity of $68.2 \%$, while fraction II showed the lowest activity of $24.33 \%$. Similar result was also reported that the ACE inhibitory activities of the corn hydrolysate with $\mathrm{M}_{\mathrm{W}}<1 \mathrm{kDa}$ showed the most potent ACE inhibitory activity (Huang et al., 2011). The results suggested that peptide with lower $\mathrm{M}_{\mathrm{W}}$ exhibited stronger ACE inhibitory activity than peptides with higher $\mathrm{M}_{\mathrm{W}}$. This tendency was also observed in peptides derived from sea cucumber that the fraction with $\mathrm{M}_{\mathrm{w}}<3 \mathrm{kDa}$ showed stronger ACE inhibitory activity than that of other fractions with higher $\mathrm{M}_{\mathrm{w}}$ (Zhong et al., 2018). This may be explained that peptide with lower $\mathrm{M}_{\mathrm{W}}$ can preferentially pass through the gap and bind with the active sites of ACE (Wilson et al., 2011). In addition, as an orally administered peptide, it was proposed that the lower $M_{W}$ peptide was more resistant to hydrolysis by various proteinases and was more readily absorbed into the intestinal tissue and transported to the site of action in vivo

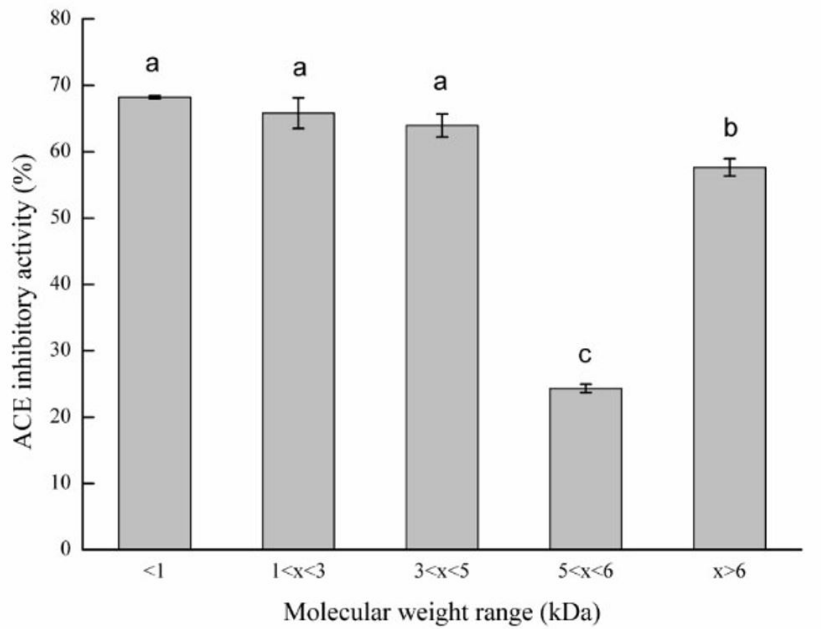

Figure 3. ACE inhibitory activity of different ultrafiltration fractions. Results are mean values of at least three replicates. The concentration of peptides is $1 \mathrm{mg} / \mathrm{ml}$. a, b, c within column, means without a common letter are significantly different, $\mathrm{P}<0.05$. 
(Ding et al., 2014). Therefore, the fraction $\mathrm{V}(<1 \mathrm{kDa})$ was selected for further research.

The fraction $\mathrm{V}(<1 \mathrm{kDa})$ was then analyzed by HPLC-ESI-MS/MS, with an electro-spray ionization (ESI) source. Over 40 molecular ion peaks were chosen for further analysis due to the high response values. Through analysis of these molecular ion peaks, 83 kinds of the peptides were obtained with average polymerization degree of 2-5. The overall results of database comparison of peptides were listed in the Supplementary Material.

According to the previous reports on the relationship between structure and activity of ACE inhibitory peptides, ACE inhibitory activity was strongly influenced by the C-terminal amino hydrophobic or aromatic residues such as Trp, Tyr, Pro and Phe. When the N-terminal contains long chain or branched chain of hydrophobic amino acids, including Ile (I), Leu (L) and $\mathrm{Val}(\mathrm{V})$, the ACE inhibitory activity is higher (Harrison \& Acharya, 2014). Meanwhile, when the third amino acid residue from C-terminal is Ile (I), Leu (L) or Trp (W), it can enhance the ACE inhibitory activity (Majumder \& Wu, 2011). Thus, four most typical peptides, Ile-Arg (IR), His-Pro-Ala (HPA), Ile-Leu-Lys-Pro (ILKP) and Ile-Asn-Ser-Trp (INSW), based on the theory were chosen and then synthesized. The ACE inhibitory activity of peptides ILKP, INSW and fraction $(<1 \mathrm{kDa})$ were $69.8 \%, 55.16 \%$ and $50.83 \%$ (Figure 4 ). It was obvious that the ACE inhibitory activity of ILKP and INSW were significantly higher than fraction $(<1 \mathrm{kDa})$. ILKP was further studied on the relationship of concentration and ACE inhibitory activity. The $\mathrm{IC}_{50}$ value of ILKP was $0.355 \mathrm{mM}$ from the regression equation $\mathrm{y}=-0.0007 \mathrm{x}^{2}+0.4169 \mathrm{x}\left(\mathrm{R}^{2}=0.9959\right)$.

In this study, the amino acid Ile (I) and Leu (L), which have the same molecular weight, appeared in IR, ILKP and INSW. These two typical amino acids came in pairs in the ILKP. It was also reported in other ACE inhibitory peptides, such as the Leu-Tyr $\left(\mathrm{IC}_{50}=1.87 \mathrm{mM}\right)$, Arg-Ala-Leu-Pro

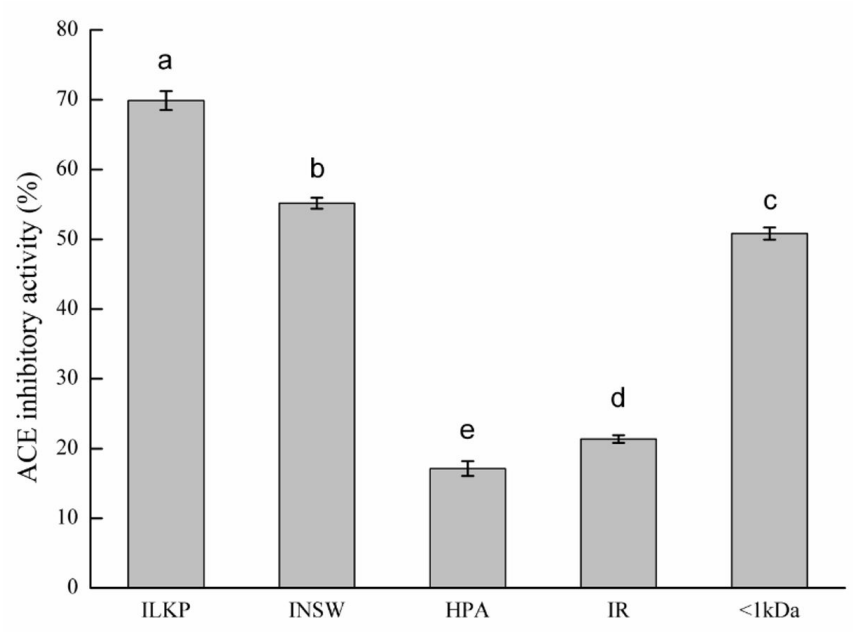

Figure 4. ACE inhibitory activity of synthetic peptides and fraction $(<1 \mathrm{kDa})$. Results are mean values of at least three replicates. The concentration of peptides is $1 \mathrm{mg} / \mathrm{mL}$. a, b, c, d, e within column, means without a common letter are significantly different, $\mathrm{P}<0.05$.
$\left(\mathrm{IC}_{50}=0.97 \mathrm{mM}\right)$ from rapeseed protein (He et al., 2013), Ala-Ser-Leu $\left(\mathrm{IC}_{50}=102.15 \mathrm{mM}\right)$ from the silkworm chrysalis protein (Wu et al., 2015), and Met-Ile-Leu-Leu-Phe-Arg $\left(\mathrm{IC}_{50}=0.12 \mathrm{mM}\right)$ from tilapia (Toopcham et al., 2015). These results showed that the branched chain amino acid Leu (L) had great influence on the activity of ACE inhibitory both in the C-terminal and $\mathrm{N}$-terminal, especially when Ile (I) and Leu (L) repeated in a peptide sequence, which could produce synergistic effect and improved the activity of the ACE inhibitory peptides.

The present study also showed that the amino acid Pro (P) had different effects depending on the location in the sequence of peptides. As for the synthesized peptides HPA and ILKP, the ACE inhibitory activity of ILKP was significantly higher than HPA. It may be reasoned that the hydrophobic amino acids Pro (P) had positive influence on the ACE inhibitory activity as C-terminal residue. The Pro-Val-Asn-Asn-Pro-Gln-Ile-His in the small red bean with the $\mathrm{IC}_{50}$ value of $206.7 \mu \mathrm{M}$ (Rui et al., 2013), and Val-Glu-Leu-Tyr-Pro with the $\mathrm{IC}_{50}$ value of $5.22 \mu \mathrm{M}$ from squid muscle (Balti et al., 2015) were consistent with the findings in our study.

\subsection{Molecular docking simulation}

The docking results for the interaction of ILKP and INSW with ACE were shown in Figure 5. Through the analysis of scoring functions, the best pose for ILKP and INSE were obtained (Figure 5A, C) with binding energy value of $-32.040 \mathrm{~kJ} / \mathrm{mol}$ and $-28.510 \mathrm{~kJ} / \mathrm{mol}$. As for the interaction forces, the binding mode between ACE residues and ILKP were hydrogen bonds, electrostatic, hydrophobic and hydrophilic force (Figure 5B), which was the same with INSW (Figure 5D) except for the presence of $\mathrm{Zn}$ at the ACE active site. The binding mode was in coincidence with most of ACE inhibitory peptides, such as the Lys-His-Val $\left(\mathrm{IC}_{50}=12.82 \mu \mathrm{M}\right)$ from silkworm pupa (Jia et al., 2015), Val-His-Trp $\left(\mathrm{IC}_{50}=0.91 \mu \mathrm{M}\right)$ from chlorella vulgaris (Xie et al., 2018) and IGPR $\left(\mathrm{IC}_{50}=0.43 \mathrm{mM}\right.$ ) from salmo salar (Yu et al., 2018).

The peptides ILKP and INSW contacted with both hydrophobic and hydrophilic residues of ACE. ILKP interacted with three hydrophobic residues and nineteen hydrophilic residues of ACE (Figure 5B). INSW interacted with two hydrophobic residues and eighteen hydrophilic residues of ACE (Figure 5D). Accordingly, ILKP contacts with ACE by more residues and gets more stable conjunction. The previous studies reported that hydrogen bonds played the most important role in stabilizing the docking complex (Chaudhary et al., 2009). In this study, hydrogen bonds were also found to be necessary in binding mode. ILKP formed three hydrogen bonds with residues Glu362, Ala332 and Lys489 of ACE. INSW generated five hydrogen bonds with residues Glu362, His491, His331 and Ala332 of ACE (Figure 5B, 5D).

ACE has three main active site pockets (S1, S2 and S1'). S1 pocket includes residues Ala354, Glu384 and Tyr523, and S2 pocket includes residues Gln281, His353, Lys511, His513 and Tyr520, while S1' contains residue Glu162 (Abdelhedi et al., 2018). However, the suggested active residues were not involved in the contact between ILKP and ACE or INSW and ACE, which was responsible for the lower inhibitory activity than ACE inhibitory 


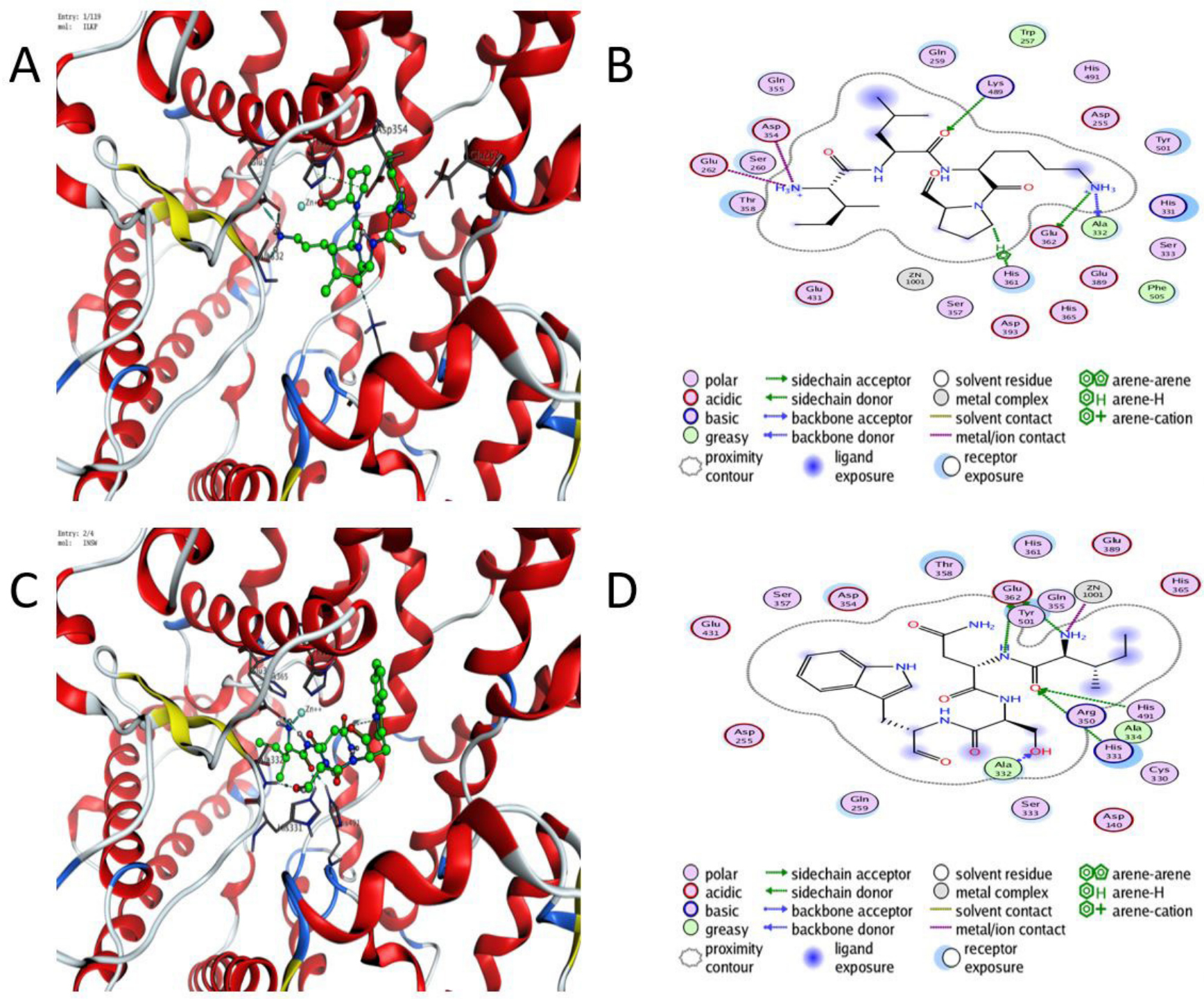

Figure 5. The molecular docking results for the interaction of ILKP and INSW with ACE (PDB: 5amb). (A) General overview of docking pose of ILKP (green stick model) at the ACE active site; (B) The binding mode between ACE residues and ILKP (green stick model) after docking at the ACE active site; (C) General overview of docking pose of INSW (green stick model) at the ACE active site; (D) The binding mode between ACE residues and INSW (green stick model) after docking at the ACE active site. $\mathrm{Zn}$ is represented in ball. Green and blue dotted lines indicate hydrogen bond formation while magenta dotted lines indicate electrostatic force formation.

peptide Gly-Asn-Gly-Ser-Gly-Tyr-Val-Ser-Arg $\left(\mathrm{IC}_{50}=14.5 \mu \mathrm{M}\right)$ explored from sipuncula (Guo et al., 2017), binding with Glu384 and Tyr523 of S1 pocket. It was also the reason why identified LeuLeu established higher inhibitory activity confirmed to be bind with His353, Ala354 and Glu384 (Pan et al., 2012).

Nevertheless, other active residues were found in our research. It was observed that Histidine (His491, His331, His365, His361), Glutamate (Glu362, Glu262, Glu431, Glu389), and Alanine (Ala332) are the main amino acid sites in docking process. Glu362 and Ala332 were involved in hydrogen bonds interaction with ILKP and INSW respectively. Thus, the residues Glu362 and Ala332 may be important sites in molecular docking between ACE and ACE inhibitory peptides (Lan et al., 2015; Liu et al., 2016). Meanwhile, the N-terminal amino of Ile (I) in
ILKP and INSW was demonstrated to create hydrogen bonds and electrostatic force on $\mathrm{Zn}$, which was in agreement with the previous prediction that the N-terminal Ile(I) or Leu (L) could increase the ACE inhibitory activity of peptides (Ferreira et al., 2007; Balti et al., 2015).

\section{Conclusion}

The promamex was chosen as the protease to hydrolyze the desalted duck egg white. Eighty-three peptides were successfully identified to exhibit high ACE inhibitory activity relatively. The most typical peptide sequence was ILKP. The molecular docking studies revealed that nine amino acids in the ACE active site greatly contributed to stabilize the docking complex. This study suggested that the ACE inhibitory peptide derived from 
desalted duck egg white could be utilized to develop functional foods for prevention of hypertension. Further work needs to be conducted to demonstrate in vivo antihypertensive activity of ILKP.

\section{Conflict of interest}

The author(s) declared no potential conflicts of interest with respect to the research, authorship, and/or publication of this article.

\section{Author contributions}

Haitao Li and Tao Hou proposed and designed the experiment. Haitao Li, Xiaoyan Chen, Yan Guo, and Tao Hou all participated in the experiment. Haitao Li and Jun Hu analyzed the data and wrote the manuscript. Tao Hou and Jun Hu revised the manuscript and were responsible for the supervision of the whole research.

\section{References}

Abdelhedi, O., Nasri, R., Mora, L., Jridi, M., Toldra, F., \& Nasri, M. (2018). In silico analysis and molecular docking study of angiotensin I-converting enzyme inhibitory peptides from smooth-hound viscera protein hydrolysates fractionated by ultrafiltration. Food Chemistry, 239, 453-463. http://dx.doi.org/10.1016/j.foodchem.2017.06.112. PMid:28873590.

Abeyrathne, E. D. N. S., Huang, X., \& Ahn, D. U. (2018). Antioxidant, angiotensin-converting enzyme inhibitory activity and other functional properties of egg white proteins and their derived peptides - a review. Poultry Science, 97(4), 1462-1468. http://dx.doi.org/10.3382/ps/ pex399. PMid:29340654.

Balti, R., Bougatef, A., Sila, A., Guillochon, D., Dhulster, P., \& NedjarArroume, N. (2015). Nine novel angiotensin I-converting enzyme (ACE) inhibitory peptides from cuttlefish (Sepia officinalis) muscle protein hydrolysates and antihypertensive effect of the potent active peptide in spontaneously hypertensive rats. Food Chemistry, 170, 519-525. http://dx.doi.org/10.1016/j.foodchem.2013.03.091. PMid:25306378.

Chaudhary, S., Vats, I. D., Chopra, M., Biswas, P., \& Pasha, S. (2009). Effect of varying chain length between P-1 and P-1 'position of tripeptidomimics on activity of angiotensin-converting enzyme inhibitors. Bioorganic \& Medicinal Chemistry Letters, 19(15), 43644366. http://dx.doi.org/10.1016/j.bmcl.2009.05.079. PMid:19523823.

Cinq-Mars, C. D., \& Li-Chan, E. C. Y. (2007). Optimizing angiotensin I-converting enzyme inhibitory activity of pacific hake (Merluccius productus) fillet hydrolysate using response surface methodology and ultrafiltration. Journal of Agricultural and Food Chemistry, 55(23), 9380-9388. http://dx.doi.org/10.1021/jf0713354. PMid:17929886.

Connolly, A., O'Keeffe, M. B., Piggott, C. O., Nongonierma, A. B., \& FitzGerald, R. J. (2015). Generation and identification of Angiotensin Converting Enzyme (ACE) inhibitory peptides from a brewers' spent grain protein isolate. Food Chemistry, 176, 64-71. http://dx.doi. org/10.1016/j.foodchem.2014.12.027. PMid:25624207.

Cushman, D. W., \& Cheung, H. S. (1971). Spectrophotometric assay and properties of the Angiotensin-Converting Enzyme of rabbit lung. Biochemical Pharmacology, 20(7), 1637-1648. http://dx.doi. org/10.1016/0006-2952(71)90292-9. PMid:4355305.

Ding, L., Zhang, Y., Jiang, Y. Q., Wang, L. Y., Liu, B. Q., \& Liu, J. B. (2014). Transport of egg white ACE-inhibitory peptide, Gln-Ile-Gly-LeuPhe, in human intestinal Caco-2 cell monolayers with Cytoprotective
Effect. Journal of Agricultural and Food Chemistry, 62(14), 3177-3182. http://dx.doi.org/10.1021/jf405639w. PMid:24670259.

Feng, S., Limwachiranon, J., Luo, Z., Shi, X., \& Ru, Q. (2016). Preparation and purification of angiotensin-converting enzyme inhibitory peptides from hydrolysate of shrimp (Litopenaeus vannamei) shell waste. International Journal of Food Science \& Technology, 51(7), 1610-1617. http://dx.doi.org/10.1111/ijfs.13131.

Ferreira, I., Pinho, O., Mota, M. V., Tavares, P., Pereira, A., Goncalves, M. P., Torres, D., Rocha, C., \& Teixeira, J. A. (2007). Preparation of ingredients containing an ACE-inhibitory peptide by tryptic hydrolysis of whey protein concentrates. International Dairy Journal, 17(5), 481-487. http://dx.doi.org/10.1016/j.idairyj.2006.06.023.

Forghani, B., Zarei, M., Ebrahimpour, A., Philip, R., Bakar, J., Hamid, A. A., \& Saari, N. (2016). Purification and characterization of angiotensin converting enzyme-inhibitory peptides derived from Stichopus horrens: stability study against the ACE and inhibition kinetics. Journal of Functional Foods, 20, 276-290. http://dx.doi. org/10.1016/j.jff.2015.10.025.

Fu, Y., Young, J. F., Lokke, M. M., Lametsch, R., Aluko, R. E., \& Therkildsen, M. (2016). Revalorisation of bovine collagen as a potential precursor of angiotensin 1-converting enzyme (ACE) inhibitory peptides based on in silico and in vitro protein digestions. Journal of Functional Foods, 24, 196-206. http://dx.doi.org/10.1016/j.jff.2016.03.026.

Garcia-Moreno, P. J., Espejo-Carpio, F. J., Guadix, A., \& Guadix, E. M. (2015). Production and identification of angiotensin I-converting enzyme (ACE) inhibitory peptides from Mediterranean fish discards. Journal of Functional Foods, 18, 95-105. http://dx.doi.org/10.1016/j. jff.2015.06.062.

Grootaert, C., Matthijs, B., Voorspoels, S., Possemiers, S., Smagghe, G., \& Van Camp, J. (2017). Egg-derived bioactive peptides with ACEinhibitory properties: a literature update. Food \& Function, 8(11), 3847-3855. http://dx.doi.org/10.1039/C7FO00839B. PMid:28944806.

Guo, M., Chen, X., Wu, Y., Zhang, L., Huang, W., Yuan, Y., Fang, M., Xie, J., \& Wei, D. (2017). Angiotensin I-converting enzyme inhibitory peptides from Sipuncula (Phascolosoma esculenta): purification, identification, molecular docking and antihypertensive effects on spontaneously hypertensive rats. Process Biochemistry, 63, 84-95. http://dx.doi.org/10.1016/j.procbio.2017.08.009.

Harrison, C., \& Acharya, K. R. (2014). ACE for all - a molecular perspective. Journal of Cell Communication and Signaling, 8(3), 195210. http://dx.doi.org/10.1007/s12079-014-0236-8. PMid:25027949.

He, R., Malomo, S. A., Alashi, A., Girgih, A. T., Ju, X., \& Alulko, R. E. (2013). Purification and hypotensive activity of rapeseed proteinderived renin and angiotensin converting enzyme inhibitory peptides. Journal of Functional Foods, 5(2), 781-789. http://dx.doi. org/10.1016/j.jff.2013.01.024.

Huang, W. H., Sun, J., He, H., Dong, H. W., \& Li, J. T. (2011). Antihypertensive effect of corn peptides, produced by a continuous production in enzymatic membrane reactor, in spontaneously hypertensive rats. Food Chemistry, 128(4), 968-973. http://dx.doi. org/10.1016/j.foodchem.2011.03.127.

Jia, J., Wu, Q., Yan, H., \& Gui, Z. (2015). Purification and molecular docking study of a novel angiotensin-I converting enzyme (ACE) inhibitory peptide from alcalase hydrolysate of ultrasonic-pretreated silkworm pupa (Bombyx mori) protein. Process Biochemistry, 50(5), 876-883. http://dx.doi.org/10.1016/j.procbio.2014.12.030.

Jimsheena, V. K., \& Gowda, L. R. (2010). Arachin derived peptides as selective angiotensin I-converting enzyme (ACE) inhibitors: Structure-activity relationship. Peptides, 31(6), 1165-1176. http:// dx.doi.org/10.1016/j.peptides.2010.02.022. PMid:20214946. 
Kaewmanee, T., Benjakul, S., \& Visessanguan, W. (2011). Effect of $\mathrm{NaCl}$ on thermal aggregation of egg white proteins from duck egg. Food Chemistry, 125(2), 706-712. http://dx.doi.org/10.1016/j. foodchem.2010.09.072.

Lan, X., Liao, D., Wu, S., Wang, F., Sun, J., \& Tong, Z. (2015). Rapid purification and characterization of angiotensin converting enzyme inhibitory peptides from lizard fish protein hydrolysates with magnetic affinity separation. Food Chemistry, 182, 136-142. http://dx.doi. org/10.1016/j.foodchem.2015.02.004. PMid:25842319.

Li, Y., Sadiq, F. A., Liu, T., Chen, J., \& He, G. (2015). Purification and identification of novel peptides with inhibitory effect against angiotensin I-converting enzyme and optimization of process conditions in milk fermented with the yeast Kluyveromyces marxianus. Journal of Functional Foods, 16, 278-288. http://dx.doi. org/10.1016/j.jff.2015.04.043.

Lin, Q. L., Liao, W., Bai, J., Wu, W., \& Wu, J. P. (2017). Soy protein-derived ACE-inhibitory peptide LSW (Leu-Ser-Trp) shows anti-inflammatory activity on vascular smooth muscle cells. Journal of Functional Foods, 34, 248-253. http://dx.doi.org/10.1016/j.jff.2017.04.029.

Liu, J. B., Yu, Z. P., Zhao, W. Z., Lin, S. Y., Wang, E. L., Zhang, Y., Hao, H., Wang, Z. Z., \& Chen, F. (2010). Isolation and identification of angiotensin-converting enzyme inhibitory peptides from egg white protein hydrolysates. Food Chemistry, 122(4), 1159-1163. http:// dx.doi.org/10.1016/j.foodchem.2010.03.108.

Liu, X., Zhang, M., Shi, Y., Qiao, R., Tang, W., \& Sun, Z. (2016). Production of the angiotensin I converting enzyme inhibitory peptides and isolation of four novel peptides from jellyfish (Rhopilema esculentum) protein hydrolysate. Journal of the Science of Food and Agriculture, 96(9), 3240-3248. http://dx.doi.org/10.1002/jsfa.7507. PMid:26494047.

Majumder, K., \& Wu, J. P. (2011). Purification and characterisation of angiotensin I converting enzyme (ACE) inhibitory peptides derived from enzymatic hydrolysate of ovotransferrin. Food Chemistry, 126(4), 1614-1619. http://dx.doi.org/10.1016/j.foodchem.2010.12.039. PMid:25213935.

Miguel, M., Lopez-Fandino, R., Ramos, M., \& Aleixandre, A. (2006). Long-term intake of egg white hydrolysate attenuates the development of hypertension in spontaneously hypertensive rats. Life Sciences, 78(25), 2960-2966. http://dx.doi.org/10.1016/j.lfs.2005.11.025. PMid:16386762.

Miguel, M., Recio, I., Gomez-Ruiz, J. A., Ramos, M., \& Lopez-Fandino, R. (2004). Angiotensin I-converting enzyme inhibitory activity of peptides derived from egg white proteins by enzymatic hydrolysis. Journal of Food Protection, 67(9), 1914-1920. http://dx.doi. org/10.4315/0362-028X-67.9.1914. PMid:15453581.

Mirdhayati, I., Hermanianto, J., Wijaya, C. H., Sajuthi, D., \& Arihara, K. (2016). Angiotensin converting enzyme (ACE) inhibitory and antihypertensive activities of protein hydrolysate from meat of Kacang goat (Capra aegagrus hircus). Journal of the Science of Food and Agriculture, 96(10), 3536-3542. http://dx.doi.org/10.1002/ jsfa.7538. PMid:26592204.

Ngo, D., Vo, T., Ryu, B. M., \& Kim, S. (2016). Angiotensin- I- Converting Enzyme (ACE) inhibitory peptides from Pacific cod skin gelatin using ultrafiltration membranes. Process Biochemistry, 51(10), 1622-1628. http://dx.doi.org/10.1016/j.procbio.2016.07.006.

O’Keeffe, M. B., Norris, R., Alashi, M. A., Aluko, R. E., \& FitzGerald, R. J. (2017). Peptide identification in a porcine gelatin prolyl endoproteinase hydrolysate with angiotensin converting enzyme (ACE) inhibitory and hypotensive activity. Journal of Functional Foods, 34, 77-88. http://dx.doi.org/10.1016/j.jff.2017.04.018.
Pan, D., Cao, J., Guo, H., \& Zhao, B. (2012). Studies on purification and the molecular mechanism of a novel ACE inhibitory peptide from whey protein hydrolysate. Food Chemistry, 130(1), 121-126. http://dx.doi.org/10.1016/j.foodchem.2011.07.011.

Pandey, M., Kapila, R., \& Kapila, S. (2018). Osteoanabolic activity of whey-derived anti-oxidative (MHIRL and YVEEL) and angiotensinconverting enzyme inhibitory (YLLF, ALPMHIR, IPA and WLAHK) bioactive peptides. Peptides, 99, 1-7. http://dx.doi.org/10.1016/j. peptides.2017.11.004. PMid:29122669.

Rui, X., Boye, J. I., Simpson, B. K., \& Prasher, S. O. (2013). Purification and characterization of angiotensin I-converting enzyme inhibitory peptides of small red bean (Phaseolus vulgaris) hydrolysates. Journal of Functional Foods, 5(3), 1116-1124. http://dx.doi.org/10.1016/j. jff.2013.03.008.

Toopcham, T., Roytrakul, S., \& Yongsawatdigul, J. (2015). Characterization and identification of angiotensin I-converting enzyme (ACE) inhibitory peptides derived from tilapia using Virgibacillus halodenitrificans SK1-3-7 proteinases. Journal of Functional Foods, 14, 435-444. http:// dx.doi.org/10.1016/j.jff.2015.01.050.

Vukic, V. R., Vukic, D. V., Milanovic, S. D., Ilicic, M. D., Kanuric, K. G., \& Johnson, M. S. (2017). In silico identification of milk antihypertensive di- and tripeptides involved in angiotensin I-converting enzyme inhibitory activity. Nutrition Research, 46, 22-30. http://dx.doi. org/10.1016/j.nutres.2017.07.009. PMid:29173648.

Wilson, J., Hayes, M., \& Carney, B. (2011). Angiotensin-I-converting enzyme and prolyl endopeptidase inhibitory peptides from natural sources with a focus on marine processing by-products. Food Chemistry, 129(2), 235-244. http://dx.doi.org/10.1016/j.foodchem.2011.04.081. PMid:30634221.

Wu, Q., Du, J., Jia, J., \& Kuang, C. (2016). Production of ACE inhibitory peptides from sweet sorghum grain protein using alcalase: Hydrolysis kinetic, purification and molecular docking study. Food Chemistry, 199, 140-149. http://dx.doi.org/10.1016/j.foodchem.2015.12.012. PMid:26775955.

Wu, Q., Jia, J., Yan, H., Du, J., \& Gui, Z. (2015). A novel angiotensin-I converting enzyme (ACE) inhibitory peptide from gastrointestinal protease hydrolysate of silkworm pupa (Bombyx mori) protein: Biochemical characterization and molecular docking study. Peptides, 68, 17-24. http://dx.doi.org/10.1016/j.peptides.2014.07.026. PMid:25111373.

Xie, J., Chen, X., Wu, J., Zhang, Y., Zhou, Y., Zhang, L., Tang, Y., \& Wei, D. (2018). Antihypertensive effects, molecular docking study, and isothermal titration calorimetry assay of Angiotensin I-Converting Enzyme inhibitory peptides from Chlorella vulgaris. Journal of Agricultural and Food Chemistry, 66(6), 1359-1368. http://dx.doi. org/10.1021/acs.jafc.7b04294. PMid:29345929.

Yu, Z., Chen, Y., Zhao, W., Li, J., Liu, J., \& Chen, F. (2018). Identification and molecular docking study of novel angiotensin-converting enzyme inhibitory peptides from salmo salar using in silico methods. Journal of the Science of Food and Agriculture, 98(10), 3907-3914. http:// dx.doi.org/10.1002/jsfa.8908. PMid:29369350.

Yu, Z., Liu, B., Zhao, W., Yin, Y., Liu, J., \& Chen, F. (2012). Primary and secondary structure of novel ACE-inhibitory peptides from egg white protein. Food Chemistry, 133(2), 315-322. http://dx.doi. org/10.1016/j.foodchem.2012.01.032. PMid:25683401.

Yu, Z., Yin, Y., Zhao, W., Wang, F., Yu, Y., Liu, B., Liu, J., \& Chen, F. (2011a). Characterization of ACE-inhibitory peptide associated with antioxidant and anticoagulation properties. Journal of Food Science, 76(8), C1149-C1155. http://dx.doi.org/10.1111/j.17503841.2011.02367.x. PMid:22417578. 
Yu, Z., Zhao, W., Liu, J., Lu, J., \& Chen, F. (2011b). QIGLF, a novel angiotensin I-converting enzyme-inhibitory peptide from egg white protein. Journal of the Science of Food and Agriculture, 91(5), 921926. http://dx.doi.org/10.1002/jsfa.4266. PMid:21384361.

Zhang, Y. W., Shen, Y. B., Zhang, H. J., Wang, L., Zhang, H., Qian, H. F., \& Qi, X. G. (2018). Isolation, purification and identification of two antioxidant peptides from water hyacinth leaf protein hydrolysates (WHLPH). European Food Research and Technology, 244(1), 83-96. http://dx.doi.org/10.1007/s00217-017-2941-z.
Zhao, N., Hu, J., Hou, T., Ma, Z., Wang, C., \& He, H. (2014). Effects of desalted duck egg white peptides and their products on calcium absorption in rats. Journal of Functional Foods, 8, 234-242. http:// dx.doi.org/10.1016/j.jff.2014.03.022.

Zhong, C., Sun, L., Yan, L., Lin, Y., Liu, G., \& Cao, M.-J. (2018). Production, optimisation and characterisation of angiotensin converting enzyme inhibitory peptides from sea cucumber (Stichopus japonicus) gonad. Food \& Function, 9(1), 594-603. http://dx.doi.org/10.1039/ C7FO01388D. PMid:29271447. 


\section{Supplementary Material}

Supplementary material accompanies this paper.

Data summary of $\mathrm{MW}<1 \mathrm{kDa}$ fractions.

This material is available as part of the online article from https://www.scielo.br/j/CTA 